\title{
Analysis of the Voting Behaviour of Czech Members of European Parliament in Areas of the Europe 2020 Strategy
}

\author{
ONDŘEJ MOCEK
}

$\frac{\text { DE }}{G} \stackrel{\substack{\text { DE GRUYTER } \\ \text { OPEN }}}{ }$

Politics in Central Europe (ISSN: 1801-3422)

Vol. 12, No. 3

DOI: $10.1515 /$ pce-2016-0016

\begin{abstract}
Aim of this paper is to analyse the behaviour of Czech MEPs in the topics related to Europe 2020 Strategy. This Strategy is one of the most important documents of recent decade on the European level and it is not so often studied on the level of the European Parliament. The purpose of this text is to find out if Czech political parties in the European Parliament are cohesive or not. The second question is related to the voting patterns, whether Czech MEPs create some kind of voting coalitions or not and if these coalitions reflect the national coalition. Methodology is based on the analyses of roll-call votes. The research period is the first two years of the 8th term of the European Parliament.
\end{abstract}

Key words: Czech MEPs, Europe 2020, RCV voting behaviour, European Parliament

\section{Introduction}

The Europe 2020 Strategy has grown into a key document for determining the course of the European Union. It sets priority improvement areas for the entire EU, including the Czech Republic. In addition to the views of the individual states charged with fulfilling these policies, it is also worthwhile to examine them from another standpoint.

1 The author's work on this article was supported by a project Evropa 2020: Horizont proměny relevantních aktérů politického systému České republiky (GA13-24657S). 
Some studies have shown that Europe 2020 is virtually overlooked in political debates at the national level (see, e.g., Hloušek et al. 2015). National actors perceive the objectives set under Europe 2020 not competitively, but strive instead to fulfil them as part of their obligation toward the EU. It is thus important to determine the extent to which these objectives constitute conflictual/consensual policies at the European level, since some policies may arouse conflict at the national level but not the European level, or vice versa. This paper focuses on the European Parliament (EP) as the sole EU institution which is directly elected. Special attention is paid to Czech representatives serving in the body, who create a case study.

Aim of this article is to verify whether Europe 2020 themes have motivated political conflict between Members of European Parliament (MEPs) that is whether these European actors differ from national actors in the areas in question in the level of contestation present. In general, this boils down to answering the question of whether themes present in the Europe 2020 Strategy, given that they do not arouse conflict at the national level, at least do so at the European level.

The paper thus emphasizes priorities set under Europe 2020 Strategy as they are reflected in voting by Czech MEPs, with the aim of determining the extent to which Czech MEPs speak with a unified voice in these areas. Further analysis will reveal which parties tend to vote together more frequently and which less so. Also investigated will be the extent to which the stances of the national coalition and the opposition are reflected in these areas, since it is possible that the national government coalition may not be mirrored in party coalitions in the EP. It is most likely that Czech MEPs will vote on the basis of their affiliations to individual political groups, rather than from their participation in the government at the national level.

In addition to examining Czech MEPs as a homogeneous unit, each political party will be dealt with separately. The analysis will reveal the degree of homogeneity Czech MEPs display within their political parties, i.e. whether their cohesion is high. The dominant opinions expressed by individual parties will also be determined and mutually compared.

The study is carried out using roll-call votes (RCV), which is one of the type of voting in the EP. The voting examined here will be to do with environmental and social issues, as well as education and research-policies for which objectives were set under the Europe 2020 Strategy.

\section{Why Europe 2020}

The Europe 2020 document was tied to the failed Lisbon Strategy. Although finalized during the global economic crisis, its objectives extended beyond achieving higher employment and a better standard of living. Key priorities 
included intelligent, sustainable, inclusive economic growth-an economy that was to develop on the basis of knowledge and innovation, aimed at a low-carbon economy and job creation, along with a reduction of poverty and social exclusion (Evropská komise 2014b, Hloušek et al. 2015: 41-44, Krutílek et al. 2010: 18).

These priorities formed the basis for the definition of specific objectives to be fulfilled by the EU as a whole. In particular, employment was to reach $75 \%$, while investment in research and innovation were to comprise $3 \%$ of GDP. Other objectives targeted climate change and sustainable energy sources: a 20\% reduction in greenhouse gases, boosting the share of energy from renewable resources by $20 \%$, and increasing energy efficiency by $20 \%$. In education, the EU objective was to reduce the share of those who do not complete their studies under $10 \%$, and to increase the share of the population with university degrees to $40 \%$. The final objective was to reduce the number of people living in poverty and social exclusion by 20 million (Evropská komise 2014a).

The individual member states reflected these objectives within their own contexts, and in specific areas, selected national goals of their own to support fulfilment of the European objectives. Although the document is not directly binding nor enforceable, the European Commission possesses several enforcement tools to compel the Member States fulfil the objectives. These are, specifically, evaluation and consultancy under the so-called European semester, during which Member States submit progress reports, among other things. Another tool is the National Reform Program, which Member States are obligated to submit, and in which they commit to steps to fulfilling the Europe 2020 objectives. In addition, the Stability and Growth Pact may be used, obliging countries to present stability programs or, in the case of non-eurozone countries, convergence programs. As part of these programs, countries describe the steps they are taking to attain a good state of public funds. The programs are then assessed by the European Commission and the Council (Hloušek et al. 2015: 45-46).

The above indicates that although Europe 2020 is not a binding set of legislative documents, it does form a substantial strategy influencing the direction taken by individual member states and the EU as a whole. For this reason, the individual areas in which Europe 2020 objectives are set were taken as key reference areas into which the EU has invested significant political capital.

\section{Study of MEP Behaviour}

The European Parliament's Rules of Procedure contain several options for voting. Most frequently used is acclamation, in which a majority is estimated by a visual check. Electronic voting is also used. Here, MEPs' votes are recorded, but the only results available or summary results, not the votes of individuals. Such votes are recorded only under RCV. Roll-call voting produces a list of names in which it can be seen whether a particular MEP voted for, against, or abstained. 
This makes clear that RCV is the only type of voting that may be utilized to examine MEP behaviour. Opinions on the information value of such an analysis vary greatly. Criticism comes from two directions: some researchers fear that the RCV may be used as a political tool, since most roll-call votes are taken at the demand of political parties, who may then use the votes as ammunition in their political battles (Hug 2012; Yordanova - Mülhlböck 2015).

Others, meantime, criticize the underlying statistics, pointing to the sample structure to argue that RCV analyses are inconclusive because votes are not evenly distributed throughout the voting population, thereby distorting the overall picture of MEP behaviour (Carrubba - Gabel 1999, Gabel - Carruba 2004, Carrubba et al. 2006, Thiem 2006). RCV ratios change over time-analyses of this sort do not always provide a precise representation of reality. The proportion of votes taken by means of RCV is estimated at one-third (Judge - Earnshaw 2009: 143). The issue is further complicated by the fact that it has been made mandatory for final votes. Specifically, since 2009, the EP Code of Procedure has mandated the use of RCV in the final vote on all legislative acts (further details in Mocek - Pitrová 2014).

There is, however, one stream of research that maintains RCV analysis is indeed conclusive. In the forefront of this group of researchers is Simon Hix (Hix et al. 2004, Hix - Noury 2009). Their focus is on the study of homogeneity/cohesion among the individual political actors of the EP. VoteWatch.eu, a website intended to provide insight into MEP voting for the public at large, also utilizes RCV as a suitable tool for examining MEP behaviour.

Other actors also point to the appropriateness of utilizing RCV analysis to explore the voting behaviour of MEPs and determine members' stands on particular themes. A study on Turkey's accession to the EU may serve as an example: it consists in spatial analyses that determine the extent to which the opinions of individual MEPs differ (Braghiroli 2012). Additional studies focus not primarily on RCV, but rather seek out the determinants of MEP behaviour by examining the votes of individual MEPs under RCV (Rasmussen 2008, Yuvaci 2013).

Thus, although the scientific community does not have a uniform opinion on the relevance of studying MEP behaviour on the basis of RCV analysis, such research is being carried out, and this has motivated its use in the present paper.

\section{Methodology}

Target of this text is Czech MEPs. All 21 MEPs elected to represent the Czech Republic during the 2014 EP elections were analysed. Specifically, these are MEPs representing ANO, ČSSD and TOP09, parties that have four representatives each. KSČM and KDU-ČSL each obtained three mandates. Two chairs were won by ODS and one by SSO. It must be noted that during the period studied, KSČM replaced an MEP after the death of member Miroslav Rans- 
dorf, who died 22 January 2016. On 4 February, 2016, his seat was taken by Jaroslav Kohlíček.

Czech political parties are present in almost all EP political groupings. KDU-ČSL and TOP09 are part of EPP, ČSSD is in S \& D and ANO in ALDE; KSČM is part of GUE-NGL and ODS has become a member of ECR. SSO joined EFDD. The specific details for Czech MEPs are given in Table 1.

\section{Table 1: A list of Czech MEPs and Their Affiliation with Political Parties and Political Groups in the EP}

\begin{tabular}{|c|c|c|}
\hline Political party & Name & EP political group \\
\hline \multirow{3}{*}{ KDU-ČSL } & Pavel Svoboda & \multirow{7}{*}{ EPP } \\
\hline & Michaela Šojdrová & \\
\hline & Tomáš Zdechovský & \\
\hline \multirow{4}{*}{ TOP09 } & Luděk Niedermayer & \\
\hline & Stanislav Polčák & \\
\hline & Jiří Pospíšil & \\
\hline & Jaromír Štětina & \\
\hline \multirow{4}{*}{ ANO } & Dita Charanzová & \multirow{4}{*}{ ALDE } \\
\hline & Martina Dlabajová & \\
\hline & Petr Ježek & \\
\hline & Pavel Telička & \\
\hline \multirow{4}{*}{ ČSSD } & Jan Keller & \multirow{4}{*}{ S\&D } \\
\hline & Pavel Poc & \\
\hline & Miroslav Poche & \\
\hline & Olga Sehnalová & \\
\hline \multirow{4}{*}{ KSČM } & Kateřina Konečná & \multirow{4}{*}{ GUE-NGL } \\
\hline & Jiří Maštálka & \\
\hline & Miloslav Ransdorf (until 22. 1. 2016) & \\
\hline & Jaroslav Kohlíček (since 4. 2. 2016) & \\
\hline \multirow{2}{*}{ ODS } & Evžen Tošenovský & \multirow{2}{*}{ ECR } \\
\hline & Jan Zahradil & \\
\hline SSO & Petr Mach & EFDD \\
\hline
\end{tabular}

Source: The author

The focus here is on themes that contain objectives under the Europe 2020 Strategy. These themes include the environment, employment, social peace, education, and research. To classify individual proposals within these categories, a selection key for individual voting sessions was developed: each item voted on has a committee responsible for it-a committee that discusses the item in question prior to any approval in the plenary session. These committees were used to classify the individual items. But because EP committees cover broader political ground than the particular segment in focus, the second criterion was developed to do with the individual DGs in the European Commission. Only relevant areas of the individual items will thus be considered. 
In addressing the issue of the Environment, the selection process was carried out on the basis of issues assigned to the Committee for the Environment, Public Health, and Food Safety; the parent DGs were either DG Environment, or DG Climate Change. For Science, the Industry, Research, and Science Committee was used, and DG Research and Innovation. Issues to do with Education were selected if they were handled by the Committee for Culture and Education, and DG Education and Culture. For this particular issue, a classification had to be made of the authors of propositions, because within both the EP and the Commission, the actors involved deal with both education and culture. To be classified as an Education issue, then, items that concerned culture were excluded, leaving only those focused on education in the study. At the EP and Commission levels, employment and social peace policies are addressed by joint bodies. For purposes of this study, therefore, these two areas were merged. The EP committee with competence was the Committee on Employment and Social Affairs, and for the DG, Employment, Social Affairs, and Social Inclusion.

This structure gave rise to four areas within which Czech MEP voting behaviour was analysed. The initial data came from the eighth EP term of office, consisting of all voting sessions that touched on the selected areas from the beginning of this period In June 2014 until the present (April 2016). This results in a period of almost two years in which Czech MEP behaviour was observed. The number of voting sessions for the individual areas targeted is depicted in Table 2.

\section{Table 2: Number of Voting Sessions in the Areas Studied}

\begin{tabular}{|c|c|}
\hline Area & Number of voting sessions \\
\hline Employment and Social Affairs & 146 \\
\hline Environment & 118 \\
\hline Education & 21 \\
\hline Research & 5 \\
\hline
\end{tabular}

The author based upon the European Parliament (undated)

The table 2 shows that voting sessions were not equally distributed among all areas in question. The number of items discussed was dependent upon how extensive the EU's powers were in the area, and the extent to which the relevant issues are addressed at the supranational level versus the national level. Employment and Social Affairs is an example of a shared policy for which competencies are divided among the EU and member states (TFEU: Art. 4 Par. 2). By contrast, Education is purely a coordinated policy, with the key role played by the Member States (TFEU 2009: Art. 6). Treaties define the Research area as follows: "In the areas of research, technological development and space, the Union shall have competence to carry out activities, in particular to define and implement programmes; however, the exercise of that competence shall not result in Member States being prevented from exercising theirs." (TFEU 2009: Art. 4 Par. 3). 
The number of voting sessions that took place, however, makes clear that the Union is not particularly active legislatively in the area.

The study includes a calculation of the cohesion among all Czech MEPs, as well as the cohesion present for individual political parties. The calculation is carried out using the Agreement Index (AI), as shown in Formula 1 (Hix et al. 2003: 317). The resulting value shows the extent to which the entity in question may be considered homogeneous. $\mathrm{Y}, \mathrm{N}$ and $\mathrm{A}$ stand for individual voting modalities, in other words, how many MEPs voted for (Yes, Y), how many against (No, $\mathrm{N}$ ), and how many abstained (A). For this type of calculation, the maximum is 1 -indicating everyone has voted identically-and the minimum 0 , the result obtained when the votes of all MEPs studied are equally distributed among all three voting modalities, i.e., there is maximum disagreement.

\section{Formula 1: Cohesion Calculation}

$$
A I_{i}=\frac{\max \left\{Y_{i}, N_{i}, A_{i}\right\}-\frac{1}{2}\left[\left(Y_{i}+N_{i}+A_{i}\right)-\max \left\{Y_{i}, N_{i}, A_{i}\right\}\right]}{\left(Y_{i}+N_{i}+A_{i}\right)}
$$

Source: Hix et al. 2003.

The second indicator is used to ascertain the dominant opinion of the individual parties. This must be brought into play whenever MEPs within a single party fail to vote identically. Because the study centres on the mutual attitudes of the political parties, which attitude is dominant within a particular party is key. Since Czech parties have only a small number of mandates, a simple rule was used: more than $50 \%$ of MEPs must vote 'Yes' on a particular issue for the stance to be designated as dominant. If no such majority is present, the party is recorded as lacking a majority opinion for that voting session, and is no longer included in the comparison. For ANO, ČSSD and TOP09, parties that hold four mandates, three MEPs represent an absolute majority. Dominant opinion may be inferred for KSČM and KDU-ČSL if an opinion is held by two out of three MEPs. Because ODS has only two mandates, both its MEPs must agree on an issue for their stance to be considered dominant. In the case of SSO, the situation is simple: the solitary MEP determines the party's dominant view.

\section{Study Results}

The first analysis focused on cohesion among Czech MEPs. The aim was to determine whether the level of homogeneity of Czech MEPs differs in the designated areas. 
Table 3: Cohesion of Czech MEPs in Areas Studied

\begin{tabular}{|c|c|}
\hline Area & Cohesion \\
\hline Employment and Social Affairs & 0.6253 \\
\hline Environment & 0.6082 \\
\hline Education & 0.6754 \\
\hline Research & 0.8649 \\
\hline
\end{tabular}

Source: The author

Table 3 makes clear that aside from Research, there is little difference in the cohesion levels of Czech MEPs. Even with the Research theme, however, it is difficult to determine whether the policy truly prompts greater consensus, or whether the few items chosen simply did not encompass many controversial themes.

Looking specifically at individual political parties, it becomes clear that the parties are fairly cohesive in all areas.

Table 4: Cohesion among Czech MEPs by Political Parties and Areas Studied

\begin{tabular}{|c|c|c|c|c|c|c|c|}
\hline Area & ANO & ČSSD & KDU-ČSL & KSČM & ODS & SSO & TOP09 \\
\hline $\begin{array}{c}\text { Employment } \\
\text { and Social Affairs }\end{array}$ & 0.9769 & 0.9692 & 0.9863 & 0.9783 & 0.9743 & $\mathrm{x}$ & 0.9384 \\
\hline Environment & 0.9703 & 0.9703 & 0.9831 & 0.8297 & 0.9873 & $\mathrm{x}$ & 0.9121 \\
\hline Education & 1.0000 & 0.9464 & 1.0000 & 0.9643 & 0.9286 & $\mathrm{x}$ & 0.9107 \\
\hline Research & 0.9250 & 1.0000 & 1.0000 & 1.0000 & 1.0000 & $\mathrm{x}$ & 1.0000 \\
\hline
\end{tabular}

Source: The author

Table 4 reveals that, with the single exception of KSČM voting on Environment, calculated cohesion remains above the 0.9 level, evidencing high homogeneity. The issue under discussion is not central: parties show a high degree of conformity in all areas studied, the single significant exception being KSČM's numbers on the Environment. But even this is not particularly dramatic-conformity remains at fairly high levels. Cohesion is not calculated for SSO since, as indicated in the Methodology, calculating cohesion for a single MEP is nonsensical.

Comparing the cohesion results for individual political groups and the overall cohesion of Czech MEPs makes clear that though the parties are homogeneous, like the Czech delegation overall, they do not agree on votes, and comprise various streams of opinion.

To determine which parties tend to vote together and which are less likely to do so, dominant party opinions were compared. The results are given in the tables below, with green designating the highest level of conformity, and red the lowest. The tables include an "Average Conformity" column which indicates the average number of instances of conformity with other political parties. In such a context, the use of the mean is not entirely logical but may serve as an indicator of potential cooperation potential. 
Table 5: Number of Conformity Instances: Dominant Party Opinions on Employment and Social Affairs

\begin{tabular}{|c|c|c|c|c|c|c|c|c|}
\hline & ANO & ČSSD & KDU-ČSL & KSČM & ODS & SSO & TOP09 & Average conformity \\
\hline ANO & $\mathrm{x}$ & 83 & 117 & 42 & 82 & 44 & 114 & 80.33 \\
\hline ČSSD & 83 & $\mathrm{x}$ & 93 & 58 & 35 & 16 & 90 & 62.50 \\
\hline KDU-ČSL & 117 & 93 & $\mathrm{x}$ & 36 & 69 & 37 & 140 & 82.00 \\
\hline KSČM & 42 & 58 & 36 & $\mathrm{x}$ & 23 & 21 & 38 & 36.33 \\
\hline ODS & 82 & 35 & 69 & 23 & $\mathrm{x}$ & 68 & 68 & 57.50 \\
\hline SSO & 44 & 16 & 37 & 21 & 68 & $\mathrm{x}$ & 35 & 36.83 \\
\hline TOP09 & 114 & 90 & 140 & 38 & 68 & 35 & $\mathrm{x}$ & 80.83 \\
\hline
\end{tabular}

Source: The author

Of the 146 total voting sessions on Employment and Social Affairs, the highest conformity is attained by TOP09 and KDU-ČSL, as evident from Table 5. In 140 cases, both parties had identical dominant opinions. The significant harmony between the two parties may be attributed to membership in the same political grouping. Their ideological proximity is thus significant, and it may be presumed that the entire grouping (and not just these two parties) coordinates its voting. ANO and KDU-ČSL, and ANO and TOP09 also have a high number of instances of conformity. Within the EP, these centrist/right-wing parties have very similar opinions on Social Affairs. In contrast, SSO and ČSSD attained the lowest number of instances of conformity at 16 . This is a very low number, which may be explained by extreme differences in thinking between social democratic ČSSD and the liberal SSO. Other examples of low conformity values may be interpreted to indicate a conflict between right-wing and left-wing, since they involve KSČM versus SSO or KSČM versus ODS. This ideological discrepancy on Social Affairs is entirely expected.

In this case, the highest cooperation potential was attained by KDU-ČSL, but they are followed closely by ANO and TOP09. In contrast, KSČM has the lowest potential, and even SSO is practically at the same low levels.

Table 6: Number of Conformity Instances: Dominant Party Opinions on Environment

\begin{tabular}{|c|c|c|c|c|c|c|c|c|}
\hline & ANO & ČSSD & KDU-ČSL & KSČM & ODS & SSO & TOP09 & Average conformity \\
\hline ANO & $\mathrm{x}$ & 73 & 90 & 40 & 48 & 17 & 87 & 59.17 \\
\hline ČSSD & 73 & $\mathrm{x}$ & 65 & 54 & 26 & 12 & 62 & 48.67 \\
\hline KDU-ČSL & 90 & 65 & $\mathrm{x}$ & 35 & 57 & 27 & 112 & 64.33 \\
\hline KSČM & 40 & 54 & 35 & $\mathrm{x}$ & 50 & 49 & 35 & 43.83 \\
\hline ODS & 48 & 26 & 57 & 50 & $\mathrm{x}$ & 68 & 56 & 50.83 \\
\hline SSO & 17 & 12 & 27 & 49 & 68 & $\mathrm{x}$ & 26 & 33.17 \\
\hline TOP09 & 87 & 62 & 112 & 35 & 56 & 26 & $\mathrm{x}$ & 63.00 \\
\hline
\end{tabular}

Source: The author 
A total of 118 voting sessions were recorded on the topic of Environment. Conformity among individual parties is indicated in Table 6. The highest number of instances of conformity came, once again, from TOP09 and KDU-ČSL. The two parties held the same position a total of 112 times. Here, too, closeness was in evidence between the centre and the right wing. Once again, ANO and KDU-ČSL, and ANO TOP09, evidenced high conformity levels. The lowest count of instances of conformity on the issue, significantly so, came with SSO and ČSSD, as was the case for Social Affairs, but SSO and ANO performed similarly. This disparity of opinion was not in evidence with the issue of Social Affairs.

Cooperation potential is once again highest for KDU-ČSL, closely followed by TOP09 and ANO. The lowest coalition potential in this area comes from SSO, followed at some distance by KSČM and ČSSD.

Table 7: Number of Conformity Instances: Dominant Party Opinions on Education

\begin{tabular}{|c|c|c|c|c|c|c|c|c|}
\hline & ANO & ČSSD & KDU-ČSL & KSČM & ODS & SSO & TOP09 & Average conformity \\
\hline ANO & $\mathrm{x}$ & 20 & 19 & 10 & 7 & 3 & 18 & 12.83 \\
\hline ČSSD & 20 & $\mathrm{x}$ & 18 & 11 & 6 & 2 & 17 & 12.33 \\
\hline KDU-ČSL & 19 & 18 & $\mathrm{x}$ & 8 & 8 & 5 & 20 & 13.00 \\
\hline KSČM & 10 & 11 & 8 & $\mathrm{x}$ & 3 & 3 & 9 & 7.33 \\
\hline ODS & 7 & 6 & 8 & 3 & $\mathrm{x}$ & 9 & 8 & 6.83 \\
\hline SSO & 3 & 2 & 5 & 3 & 9 & $\mathrm{x}$ & 5 & 4.50 \\
\hline TOP09 & 18 & 17 & 20 & 9 & 8 & 5 & $\mathrm{x}$ & 12.83 \\
\hline
\end{tabular}

Source: The author

The area of Education comprises only 21 voting sessions. Thus the results obtained may be more distorted than those for the prior two areas due to the size of the voting population. As Table 7 shows, ANO, TOP09 and KDU-ČSL, once again, have similar opinions on the policy. The highest level of conformity is attained by ANO and ČSSD, voting identically in 20 cases. The conformity levels of these two parties for prior policies were not as high as they were here. The lowest conformity level is once again shown by ČSSD and SSO (2). But SSO and ANO, and SSO and KSČM, also show very low conformity (3). The same obtains for ODS and KSČM.

The highest average conformity-indicating the greatest cooperation potential in the area of Education-was shown by KDU-ČSL, closely followed by ANO, TOP09 and ČSSD. The other side of the spectrum once again features SSO, followed by ODS and KSČM. The parties possess rather distinct opinions on this issue and evince either high levels of conformity or high levels of disagreement; there is very little room in the imaginary centre. 
Table 8: Number of Conformity Instances: Party Dominant Opinions on Research

\begin{tabular}{|c|c|c|c|c|c|c|c|c|}
\hline & ANO & ČSSD & KDU-ČSL & KSČM & ODS & SSO & TOP09 & Average conformity \\
\hline ANO & $\mathrm{x}$ & 4 & 4 & 4 & 4 & 0 & 4 & 3.33 \\
\hline ČSSD & 4 & $\mathrm{x}$ & 5 & 5 & 5 & 0 & 5 & 4.00 \\
\hline KDU-ČSL & 4 & 5 & $\mathrm{x}$ & 5 & 5 & 0 & 5 & 4.00 \\
\hline KSČM & 4 & 5 & 5 & $\mathrm{x}$ & 5 & 0 & 5 & 4.00 \\
\hline ODS & 4 & 5 & 5 & 5 & $\mathrm{x}$ & 0 & 5 & 4.00 \\
\hline SSO & 0 & 0 & 0 & 0 & 0 & $\mathrm{x}$ & 0 & 0.00 \\
\hline TOP09 & 4 & 5 & 5 & 5 & 5 & 0 & $\mathrm{x}$ & 4.00 \\
\hline
\end{tabular}

Source: The author

The Research theme is difficult to interpret. Over the period studied, only five pertinent voting sessions took place. This greatly influences the information value of the data. As Table 8 reveals, Research does not generate conflict; most parties vote identically. In all five cases, ČSSD, KDU-ČSL, KSČM, ODS and TOP09 held the same dominant opinion. ANO differed in a single case. The interesting thing is, however, that although this theme looks as if it indicates the same level of significance for consensus among Czech MEPs, Petr Mach did not vote the same as other SSO party members. He alone thereby created an imaginary opposition.

\section{Conclusion}

The focus of this paper has been on the voting of Czech MEPs in theme areas set under the Europe 2020 Strategy. The strategy was selected as the key document of the current decade, one which defines the priority policies of the contemporary EU. The strategy targets increased employment, a reduction in poverty, reduced emissions of greenhouse gases, increased energy efficiency, an increased proportion of renewable resources, a higher share of citizens with university education, lower levels of abandoned studies, and increased investment in science and research.

These objectives were then transformed into four areas for study, specifically: Employment and Social Affairs, Environment, Education, and Research. Czech MEP voting behaviour was observed on these policies.

The aim has been to verify the extent to which the policies generate conflict at the European level, since it has been demonstrated that competition in these areas is practically nonexistent at the national level. To ascertain whether such political conflict does exist at the European level, the votes of Czech MEPs were utilized. A further aim was to assess whether voting in these areas is reflected in national party composition-in other words, whether the parties that form a government coalition likewise vote together in the EP. 
The results reveal a fairly uniform cohesion situation for all Czech MEPs in the areas of Employment and Social Affairs, environment, and education. There is neither significant conformity nor significant disagreement in any of these areas. For Research, by contrast, the level of cohesion was higher, but only five voting sessions took place in the area, casting uncertainty on the results. When it comes to cohesion within individual parties, all parties studied independently evinced a high degree of homogeneity of opinion across areas. Czech political parties are homogeneous bodies in the EP, and their members coordinate their votes in these areas.

The study also focused on a comparison of the dominant opinions held by individual Czech parties in these same four areas. Here the existence of some sort of centre/right-wing coalition involving KDU-ČSL, ANO and TOP09 may be detected-these parties all acted in significant conformity with each other in all areas. The results are attributable to the parties' involvement in political groupings, since EPP and ALDE are close politically. It was no surprise that ČSSD did not join the other parties in the area of Social Affairs; however, ČSSD voted alongside the three above parties on issues to do with Education and Research. This fact confirms the assumption that the voting coalition in the EP encompasses the entire political spectrum from left to right in many areas.

The lowest level of conformity of all Czech parties in the EP was exhibited by SSO, followed by KSČM. ODS was also at relatively low levels. All these parties are part of political groupings that are positioned outside the mainstream, so the low level of co-operation was expected. The results for SSO, in particular, given that it is part of the extreme-right faction EFDD, are no surprise in this regard. The study thus confirms the rhetoric coming out of these parties, who have oftentimes felt themselves to be the opposition within the EP.

When it comes to domestic politics, given that the majority government of the CR is formed by KDU-ČSL, ANO and ČSSD, it is interesting to note that collaboration between them is not wholly apparent at the European level. As indicated above, within the EP, ČSSD does not agree with KDU-ČSL and ANO in the area of Environment and Social Affairs. In contrast, TOP09, an opposition party at the national level that hardly collaborates in Parliament with the government coalition, behaves more consensually in the areas studied at the European level. National structures are thus not reflected in the logic that drives Czech MEP voting or, if they do, they feature only to a very limited extent.

It is clear that in general, the voting of Czech MEPs is not unified. Varying streams of opinion on these policies exist within the Czech delegation; these streams are not stable, but rather differ by individual area.

Overall, the study has shown that Czech political parties are homogeneous bodies within the EP. Political and ideological proximity have proved decisive in the areas studied which, in terms of competencies, do not rank among primary EU policies but rather constitute areas in which the EU and the Member States 
have defined goals to improve the EU's competitiveness. Although it might seem that national level structures would permeate these areas, this proved not to be the case.

\section{References}

Braghiroli, Stefano (2012): Je t'aime... moi non plus! An empirical assessment of Euro-parliamentarians' voting behaviour on Turkey and Turkish membership. Southeast European and Black Sea Studies 12 (1): 1-24.

Carruba, Clifford - Gabbel, Matthew (1999): Roll-Call Votes and Party Discipline in the European Parliament. Unpublished manuscript. Paper prepared for presentation at the 1999 Meeting of European Community Studies Association: http://aei.pitt.edu/2239/1/002645_1.PDF.

Carrubba, Clifford - Gabel, Matthew - Murrah, Lacey - Clough, Ryan - Montgomery, Elizabeth Schambach, Rebecca (2006): Off the Record: Unrecorded Legislative Votes, Selection Bias and Roll-Call Votes Analysis. British Journal of Political Science 36 (4): 691-704.

Evropská komise, 2014a. Cíle strategie Evropa 2020: http://ec.europa.eu/europe2020/europe2020-in-a-nutshell/targets/index_cs.htm.

Evropská komise, 2014b. Priority strategie Evropa 2020: http://ec.europa.eu/europe2020/ europe-2020-in-a-nutshell/priorities/index_cs.htm.

Evropský parlament (undated). Zápisy z plenárních zasedání: http://www.europarl.europa.eu/ plenary/cs/minutes.html.

Gabbel, Matthew - Carruba, Clifford (2004): The European Parliament and Transnational Political Representation: Party Groups and Political Conflict: http://library.fes.de/pdf-files/ id/02609.pdf.

Hix, Simon - Kreppel, Amie - Noury, Abdul (2003): The Party System in the European Parliament: Collusive or Competitive? Journal of Common Market Studies 41 (2): 309-331.

Hix, Simon - Noury, Abdul G. - Roland, Gérard (2004): Power to the Parties: Cohesion and Competition in the European Parliament. 1979-2001: http://voteworld.berkeley.edu/eurodata/ Hix-Noury-Roland- Power\%20to\%20the\%20Parties-7jan.pdf.

Hix, Simon - Noury, Abdul G. (2009): After Enlargement: Voting Patterns in the Sixth European Parliament. Legislative Studies Quarterly 34 (2): 159-174.

Hloušek, Vít - Havlík, Vlastimil - Havlík, Vratislav - Kaniok, Petr - Mocek, Ondřej, 2015. Šance zpola využitá: Česká republika a strategie Evropa 2020. Brno: CDK.

Hug, Simon (2012). Roll call votes in the European Parliament. Paper prepared for presentation at the Annual Meeting of the American Political Science Association, New Orleans, August 30 - September 2: http://www.unige.ch/ses/spo/static/simonhug/rcvep/rcvep.pdf.

Judge, David - Earnshaw, David (2008): The European Parliament. London: Palgrave Macmillan. Krutílek, Ondřej - Kuchyňková, Petra - Frízlová, Iveta, 2010. Monitoring EU europoslance Hynka Fajmona: http://www.cdk.cz/sites/default/files/soubory/2010-03.pdf. 
Mocek, Ondřej - Pitrová, Markéta, 2014. Jmenovité hlasování v Evropském parlamentu. Mezinárodní vztahy 49 (4): 64-80.

Rasmussen, Maja Kluger, 2008. Another Side of the Story: A Qualitative Case Study of Voting Behaviour in the European Parliament. Politics 28 (1): 11-18.

Smlouva o fungování EU. 2009. In Konsolidované znění Smlouvy o Evropské unie a Smlouvy o fungování EU. Úřad vlády ČR.

Theim, Janina (2006): Explaining Roll Call Vote Request in the European Parliament. Mannheimer Zentrum für europäische Sozialforschung: http://www.mzes.uni-mannheim.de/publications/ wp/wp-90.pdf?origin=publication_detail.

Yordanova, Nikoleta - Mühlböck, Monika (2015): Tracing the selection bias in roll call votes: party group cohesion in the European Parliament. European Political Science Review 7 (3): 373-399.

Yuvaci, Abdullah, 2013. The Voting Behavior of the European Parliament Members on Turkish Accession: A Quantitative Analysis of a Special Status Amendment Vote on Turkey. Turkish Studies 14 (3): 564-580.

Ondřej Mocek is researcher at International Institute of Political Science at Masaryk University. His research focuses on the European Parliament and Czech politics. Email:206699@mail.muni.cz. 